\title{
A WEAPON FROM THE TURN OF THE EPOCHS - A UNIQUE SPATHA FROM LAKE NIDAJNO IN PRUSSIA
}

\begin{abstract}
This paper discusses the results of new technological examinations of a spatha blade from a bog sacrificial place in Lake Nidajno, Czaszkowo (Zatzkowen), Mragowo District, Prussia, PL. The site can be dated to the turn of the Late Roman Period and the Migration Period and its origin may have been related to interactions between Germanic, Balt and Black Sea and North-Eastern Mediterranean cultures, and perhaps to migrations of the Galindians to Southern Europe and back. The archaeometallurgical examinations demonstrated that the blade had been manufactured using a complex pattern-welding technology. As a result, a weapon which possessed both high combat values and unique aesthetic traits was produced. The blade itself may be of Roman provenance.
\end{abstract}

Keywords: sword, spatha, pattern-welding technology, archaeometallurgy, Roman Period, Migration Period, Prussia, Balt Culture, Galindians

Received: 18.11.2019 Revised: 07.04.2020 Accepted: 18.05.2020

Citation: Żabiński G. 2020. A Weapon from the Turn of the Epochs - A Unique Spatha from Lake Nidajno in Prussia. "Fasciculi Archaeologiae Historicae" 33, 7-20, DOI 10.23858/FAH33.2020.001

\section{Introduction}

The aim of this paper is to discuss the results of repeated technological examination of a unique spatha blade from a bog sacrificial place in Lake Nidajno, Czaszkowo (former Zatzkowen), Mrągowo District, Prussia, now within the borders of Poland (Fig. 1). This artefact and other sword finds from this site have already been analysed with regard to their technology of manufacture. ${ }^{1}$ However, a new analysis provided new pieces of information which result in a better understanding of the manufacturing technology of this extraordinary weapon. Technological examinations were carried out by Dr Janusz Stępiński, to whom the author is indebted for his kind help.

\section{Find context}

The discussed sword blade ${ }^{2}$ was discovered as part of a bog sacrifice from the turn of the Late Antiquity and

\footnotetext{
*Institute of History, Jan Długosz University in Częstochowa; (D) https://orcid.org/0000-0003-3091-1035; g.zabinski@gmail.com 1 Żabiński 2016a; Żabiński 2016 b.

${ }^{2}$ Field inv. no. Cz-P55, cat. no. 1.1.1.4 in Żabiński 2016a and Żabiński 2016b.
}

the Migration Period. The deposit was composed of over 400 artefacts made from iron and other metals, including precious ones. These were mostly ritually destroyed (burnt and bent or broken) spearheads, sword blades, mail, as well as numerous ornaments and fittings made of bronze, silver and gold. As far as the cultural pertinence of these finds is concerned, some of them can be related to the local milieu, that is, the Bogaczewo Culture and the Olsztyn Group, while others display Germanic, Black Sea or Mediterranean traits. It is believed that this site is an example of a result of migrations and other types of interactions between Germanic, Balt and Black Sea and North-Eastern Mediterranean cultures, with special reference to a theory of migrations of the Galindians to Southern Europe and back. ${ }^{3}$

\section{Spatha Cz-P55 and its manufacturing technology}

Among the finds from Czaszkowo there were five swords blades in all. Due to its extremely poor state of preservation (complete mineralisation), nothing can be

\footnotetext{
${ }^{3}$ Nowakiewicz and Rzeszotarska-Nowakiewicz 2011; Nowakiewicz and Rzeszotarska-Nowakiewicz 2012, 33-51, 53-81, 91-125, 127-132, 135-137; Nowakiewicz 2015; Nowakiewicz 2016.
} 


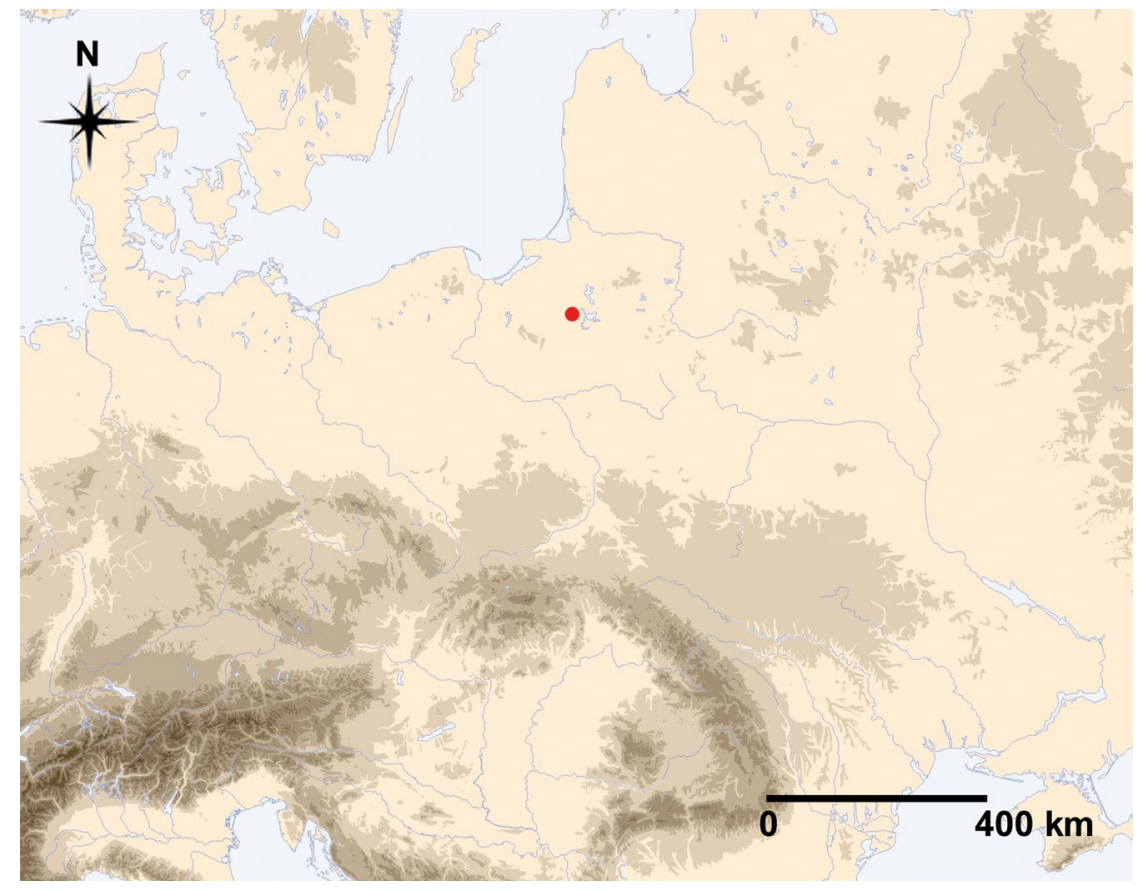

Fig. 1. Bog sacrificial site in Lake Nidajno, Czaszkowo, Mrągowo District, Prussia.

said on the technology of manufacture of Sword Blade CZ/29/1 (cat. no. 1.1.1.2). Furthermore, metallic parts which survived in the cores of Sword Blades CZ/XVIII/10 (cat. no. 1.1.1.5) and CZ/33/10 (cat. no. 1.1.1.3) are too small to render any more accurate assessment possible. As regards Sword Blade CZ/28A/10 (cat. no. 1.1.1.1), its core was manufactured from at least two rods of low-carbon steel, which would suggest that it belongs to the technological Group B.II (blades made from rods). ${ }^{4}$

The state of preservation of Sword Blade CZ-P55 (cat. no. 1.1.1.4) is far from satisfactory, too, and hardly any typochronological assessment is possible. Only the upper and a portion of the central part of the blade have survived (Fig. 2). On the other hand, it is preserved in a much better condition than the other swords from this site. Thus, much more can be said regarding its technology of manufacture.

A wedge-shaped sample (c. $18 \times 2.5 \mathrm{~mm})$ was taken for metallographic examination from the central part of the blade. The sample encompassed a half of the blade's cross-section. It was decided to apply this rather strongly invasive procedure, ast it allowed for a comprehensive of the blade's technology. Taking a small sample from the point of the blade would have obviously been less destructive, but the amount of information gained in result of such an approach would have been much smaller. The gap after sampling was filled with Axson resin and the surface of the fill was covered with Paraloid conservation layers. The

${ }^{4}$ Żabiński et al. 2014, 139-143, Fig. 49; Żabiński 2016a, 88-109, Figs. 1.31-3.16, 118-121, Figs. 5.1-5.9; Żabiński 2016b, 123-124. aim of the metallographic examinations was to identify the material used for the manufacture of the blade and to analyse the manufacturing technology.

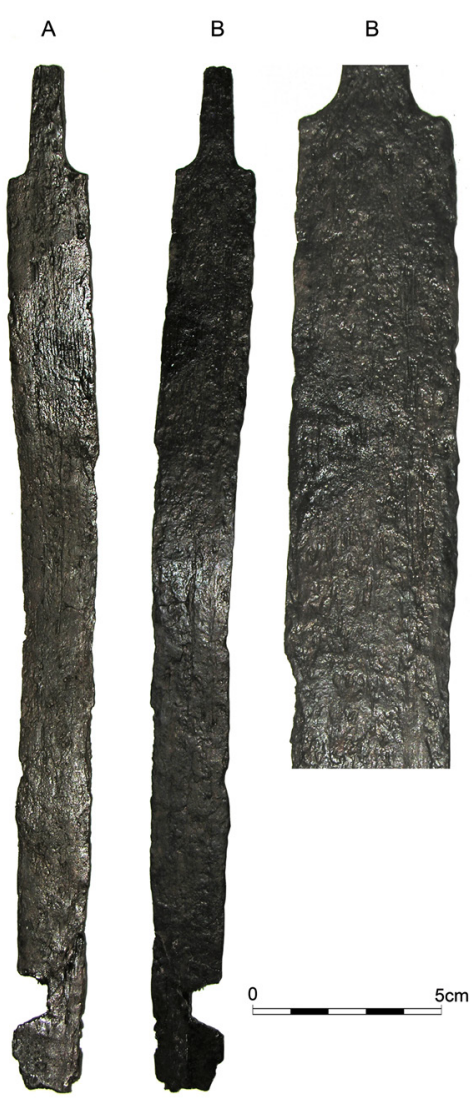

Fig. 2. Spatha CZ-P55, Czaszkowo, Mrągowo District, Prussia. General view (Sides A and B), and a close-up on Side B. Traces of pattern-welding (stripes and herringbone) can be seen. Photo G. Żabiński. 


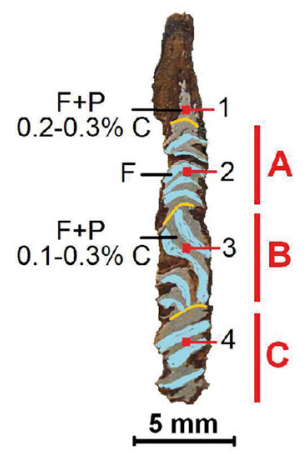

a

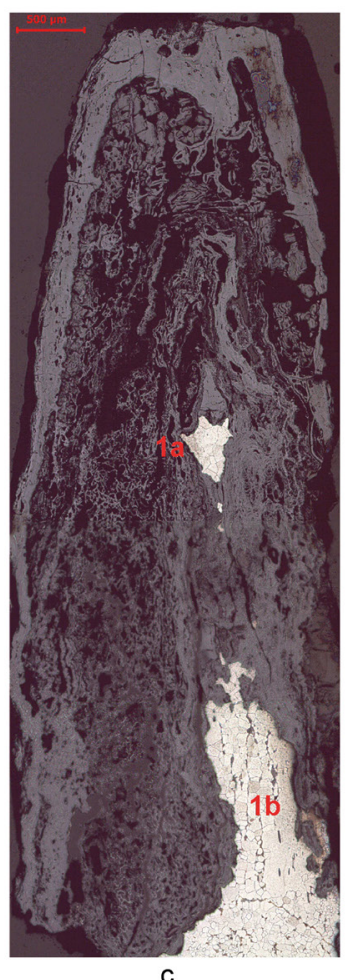

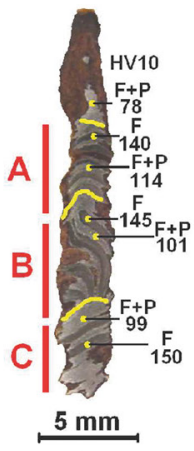

b

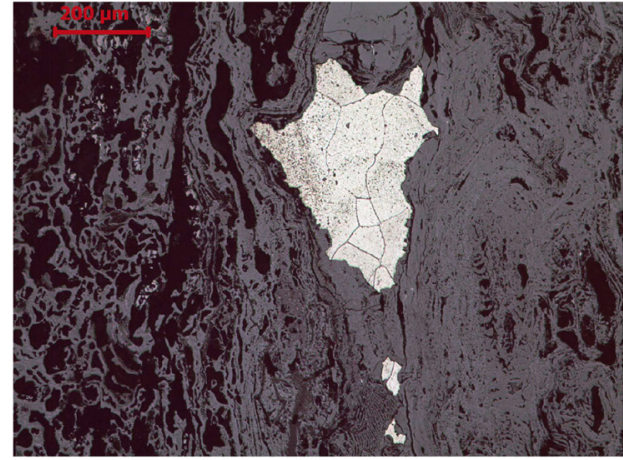

d

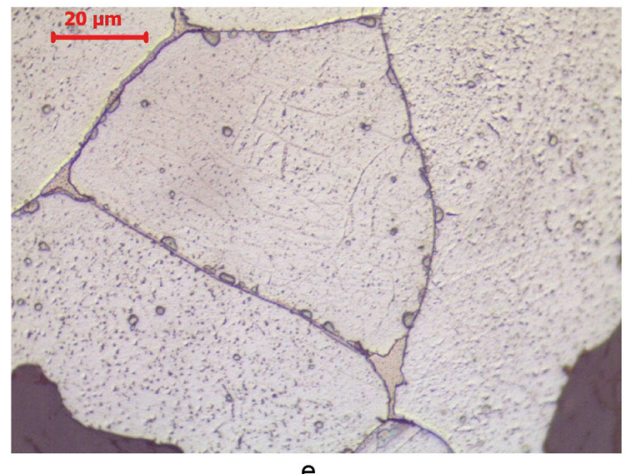

Fig. 3. Spatha CZ-P55, Czaszkowo, Mrągowo District, Prussia, microstructure of the edge: a - schematic distribution of structural components ( $\mathrm{F}$ - ferrite, $\mathrm{P}$ - pearlite, A, B, C - pattern-welded pieces of the blade's core) and spots of microscopic observations (1-4); $\mathrm{b}$ - macrostructure of the sample with HV10 hardness tests ( $\mathrm{F}$ - ferrite, $\mathrm{P}$ - pearlite, $\mathrm{A}, \mathrm{B}, \mathrm{C}$ - pattern-welded pieces of the blade's core); $\mathrm{c}$-surviving fragments of metal in the corroded edge in Spot $1 ; \mathrm{d}, \mathrm{e}$ - precipitates of tertiary cementite in the borders of ferrite grains, Zone 1a in Spot 1. Photo J. Stępiński.

\section{Research methods}

The sample was mounted in resin and then it was ground and polished with the use of diamond paste of different grits. Its surface was etched with $4 \%$ nital in order to reveal the microstructure of the sample. Microstructure observations were carried out using a Leica DMLM optical microscope. A qualitative $\mathrm{X}$-ray microanalysis of slag inclusions was done using a Hitachi S-3500N scanning microscope, equipped with an EDS-type spectrometer, with accelerating voltage of $20 \mathrm{kV}$. The content of carbon in the examined sample was approximately assessed on the basis of microscopic observations. Hardness tests were carried out using the Vickers method with a load of $10 \mathrm{kG}(98 \mathrm{~N})$.

\section{Metallographic examinations}

The macroscopic image of the sample's surface with spots of microscopic observations (1-4) and a schematic distribution of structural components and HV10 hardness tests can be seen in Fig. 3:a-b.

The examinations revealed that the blade was composed of several parts of different material. In the strongly corroded edge of the blade the microstructure changes from ferritic with tertiary cementite precipitates (Fig. 3:c-e) to ferritic-pearlitic one with the carbon content of $0.2-0.3 \% \mathrm{C}$, which corresponds to soft steel (Fig. 4:a-c).

The core of the blade was composed of three pattern-welded pieces of metal, marked as A, B, and C 


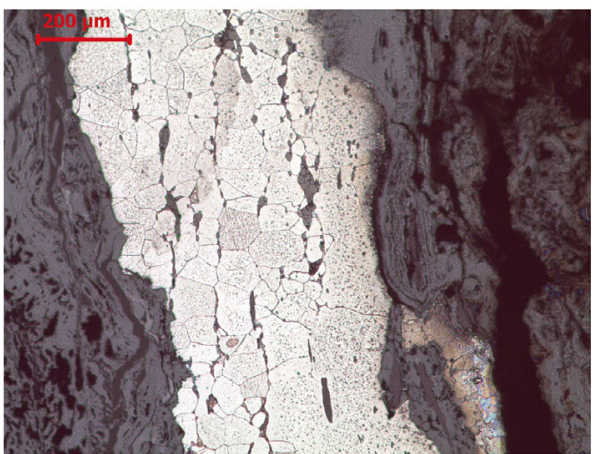

a

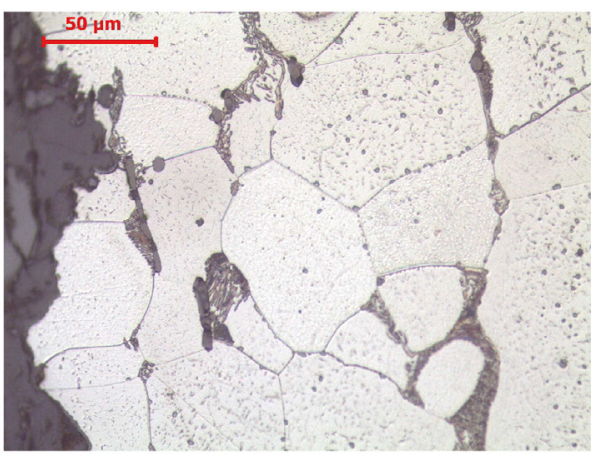

b

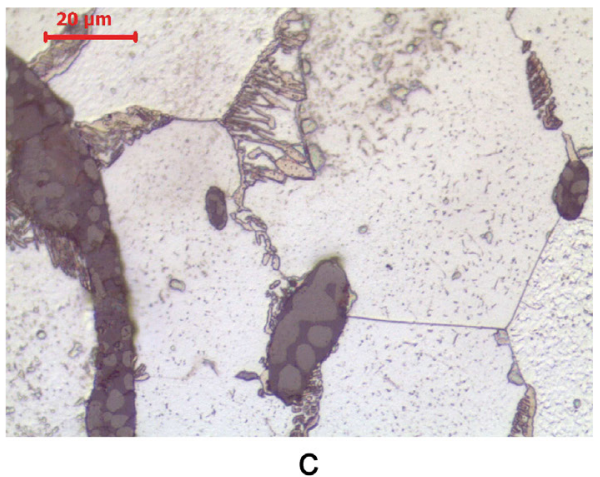

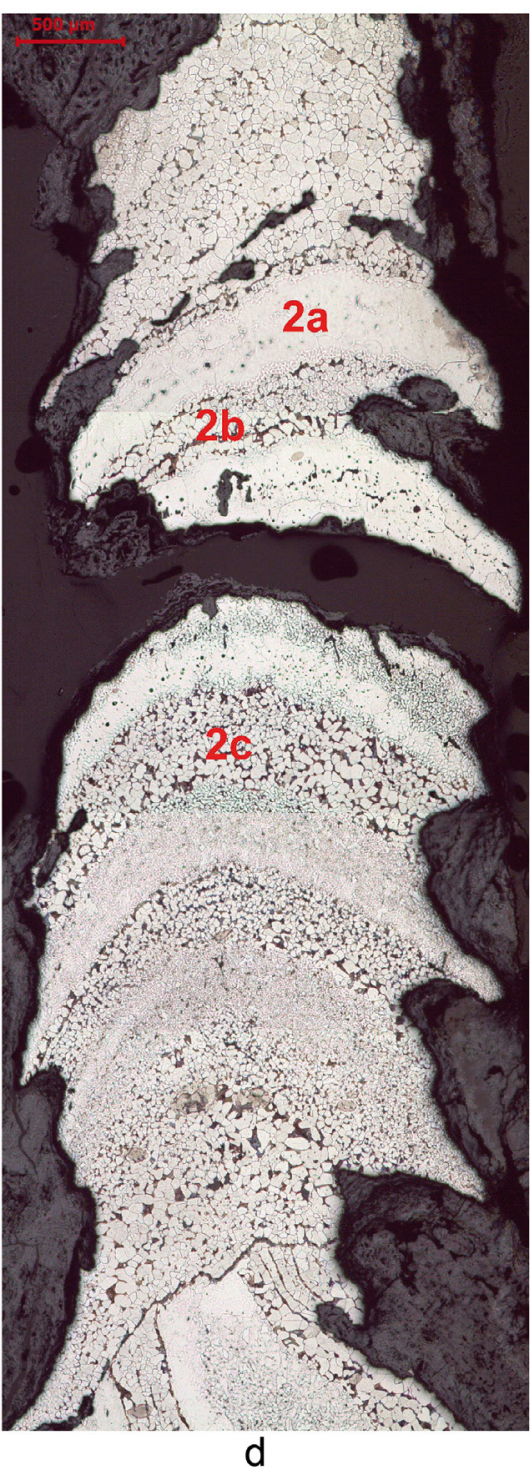

Fig. 4. Spatha CZ-P55, Czaszkowo, Mrągowo District, Prussia, microstructure of the edge and of the pattern-welded Piece A: a - surviving fragment of the edge neighbouring the pattern-welded Piece A, Zone 1b in Spot 1; b - ferritic-pearlitic microstructure in the edge of the sword, Zone 1b in Spot 1; $\mathrm{c}$ - multiphase slag inclusions and degenerated pearlite against the background of ferrite in the edge of the sword,

Zone $1 \mathrm{~b}$ in Spot 1; d-iron (ferritic) and steel (ferritic-pearlitic) layers in the pattern-welded Piece A in Spot 2. Photo J. Stępiński.

in Fig. 3:a-b. Each of these consists of several layers of soft steel with ferritic-pearlitic microstructure and the carbon content of $0.1-0.3 \% \mathrm{C}$ (Figs. 4:d, 5:c-e, 6:a, 7:a-c and $8: \mathrm{a}-\mathrm{c})$. These layers are separated by layers of ferritic iron (Figs. 4:d, 5:a-b,e-f, 6:a-d, 7:d-f, and 8:a,d-e). In the pattern-welded Pieces $A$ and $C$ the layers of iron and steel go straight from one to the other surface of the flats. However, the pattern-welded Piece B was twisted. Therefore, positions of individual layers in relation to the flats of the blade vary (Fig. 6:a). Due to this diversified alignment of the layers in Pieces A, B, and C, different patterns can be seen on the surfaces of the flats. Pieces $\mathrm{A}$ and $\mathrm{C}$ produce a banded pattern, while Piece $\mathrm{B}$ produces a herringbone pattern.

The microstructure of the iron layers is marked with a local presence of coarse grains, etching pits, ghost structures and phosphide precipitates (Figs. 5:a-b,e-f, 6:b-d, 7:d-f and 8:d-e). All these traits demonstrate an increased content of phosphorus in the iron layers of the pattern-welded blade. On the other hand, in the layers of soft steel one can see a partial degeneration of pearlite colonies (Figs. 5:c-d, 7:b-c and 8:b-c). This can also be seen in the edge of the sword (Fig. 4:b-c) and is related to prolonged heating of the blade and to the local presence of phosphorus in the metal.

As it can be seen on the surface of the sample, the surface of the blade is strongly damaged by corrosion. Large subsidences of metal are noticeable in almost every part of the blade (Figs. 3:c, 4:d, 6:a and 8:a).

Slag inclusions in individual parts of the blade are tiny and diversified with regard to their shape. Most of these are monophase. Multiphase slag inclusions can 


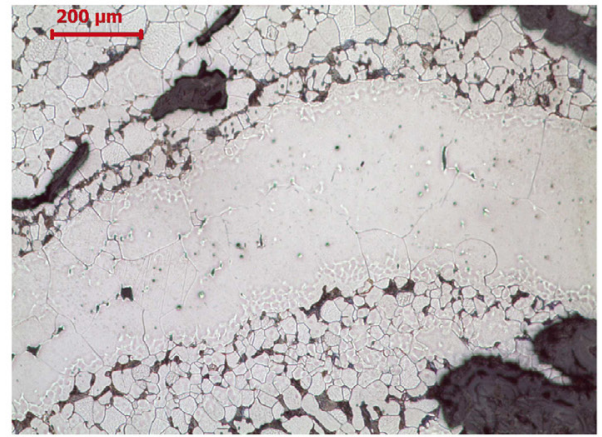

a

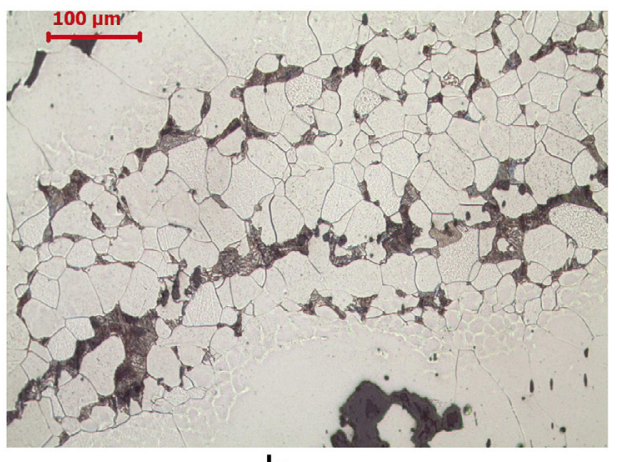

b

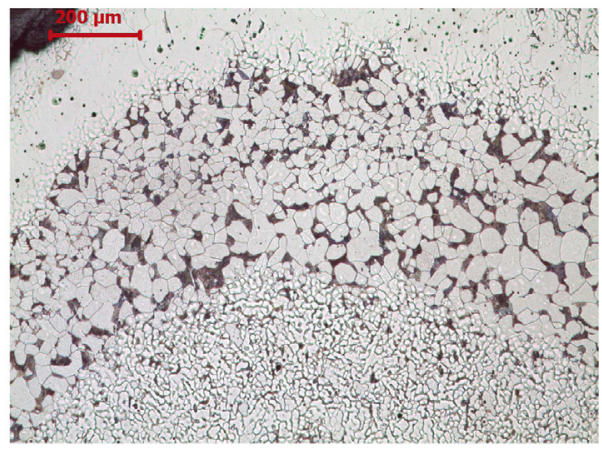

C

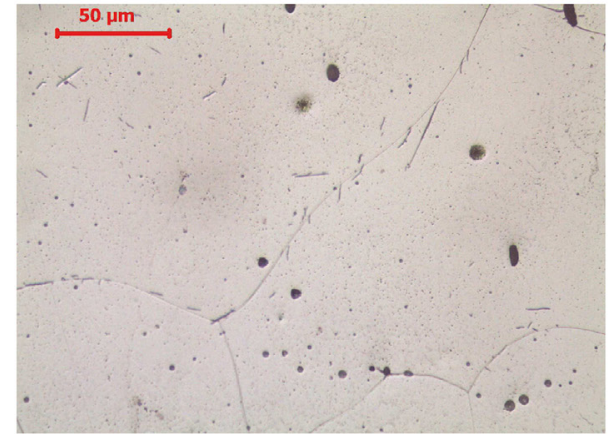

d

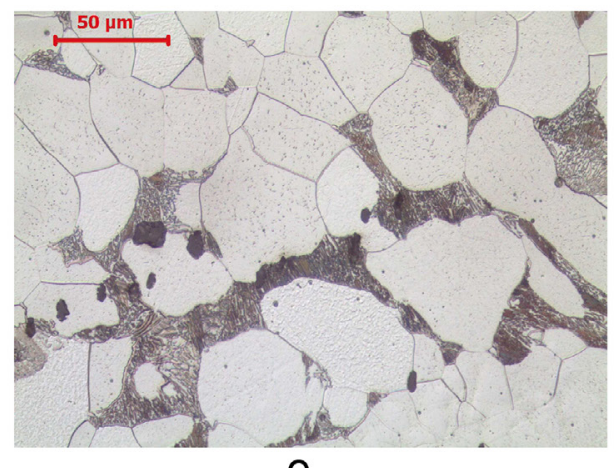

e

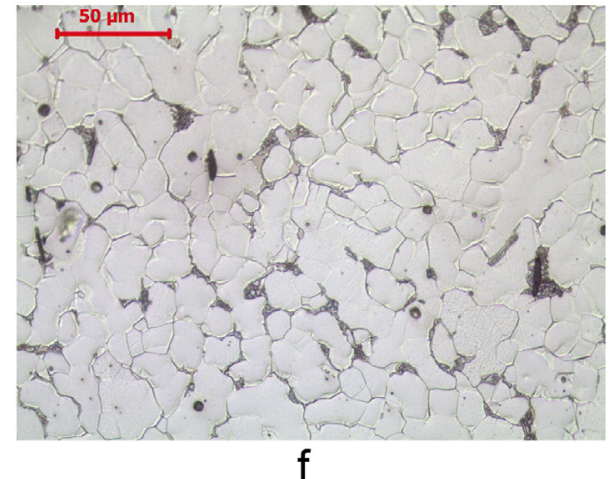

Fig. 5. Spatha CZ-P55, Czaszkowo, Mrągowo District, Prussia, microstructure of the pattern-welded Piece A: a - iron layer, Zone 2a in Spot 2; $\mathrm{b}$ - microstructure of the iron layer: coarse-grained ferrite, slag inclusions and phosphide precipitates, Zone 2a in Spot 2; c, d-ferritic-pearlitic microstructure and slag inclusions in the steel layer, Zone 2b in Spot 2; e - another example of a steel layer, Zone 2c in Spot 2;

$\mathrm{f}$ - iron layer adjacent to the steel layer in Fig. 3e, ghost structure and some carburisation can be seen, Zone 2c in Spot 2. Photo J. Stępiński.

only be found in the edge of the sword, alongside with monophase ones (Fig. 4:c).

On the basis of the EDS X-ray microanalysis of the slag inclusions in the edge of the sword it can be said that globular parts in the multiphase slag inclusions contain $\mathrm{Fe}$ and $\mathrm{O}$. Thus, these are wüstite precipitates. On the other hand, the background of these inclusions is silicate and is composed of such elements as $\mathrm{Si}, \mathrm{Fe}$, and $\mathrm{O}$ (Fig. 9:a-c). Monophase slag inclusions in the edge of the sword are also of a silicate type. Apart from Si, Fe and O, they also contain Al, Ca and K (Fig. 9:d-f). The EDS $\mathrm{X}$-ray microanalysis of slag inclusions in the layers of soft steel in the pattern-welded Pieces A, B, and C demonstrated that they contained such elements as $\mathrm{Si}, \mathrm{Fe}, \mathrm{O}, \mathrm{Al}$, $\mathrm{Ca}$, and $\mathrm{K}$, and sometimes also $\mathrm{P}$ or $\mathrm{Mn}$. Therefore, these inclusions are also of silicate type (Figs. 10:a-c, 11:a-c and 12:a-c). The same chemical composition can also be found in the analysed slag inclusions in the iron layers in the pattern-welded Pieces A, B, and C. However, in this case phosphorus is present in almost every slag inclusion (Figs. 10:d-f, 11:d-f and 12:d-f).

Hardness tests on the surface of the sample yielded the following values: in the edge of the blade 78 HV10; in Piece A - 140 HV10 in the iron layers and 114 HV10 in the steel layers; in Piece B - 145 HV10 in the iron layers and 101 HV10 in the steel layers; in Piece C -150 HV10 in the iron layers and 99 HV10 in the steel layers.

\section{Technology}

The examined sword blade is composed of rods. It was probably forged from five rods of pre-manufactured 


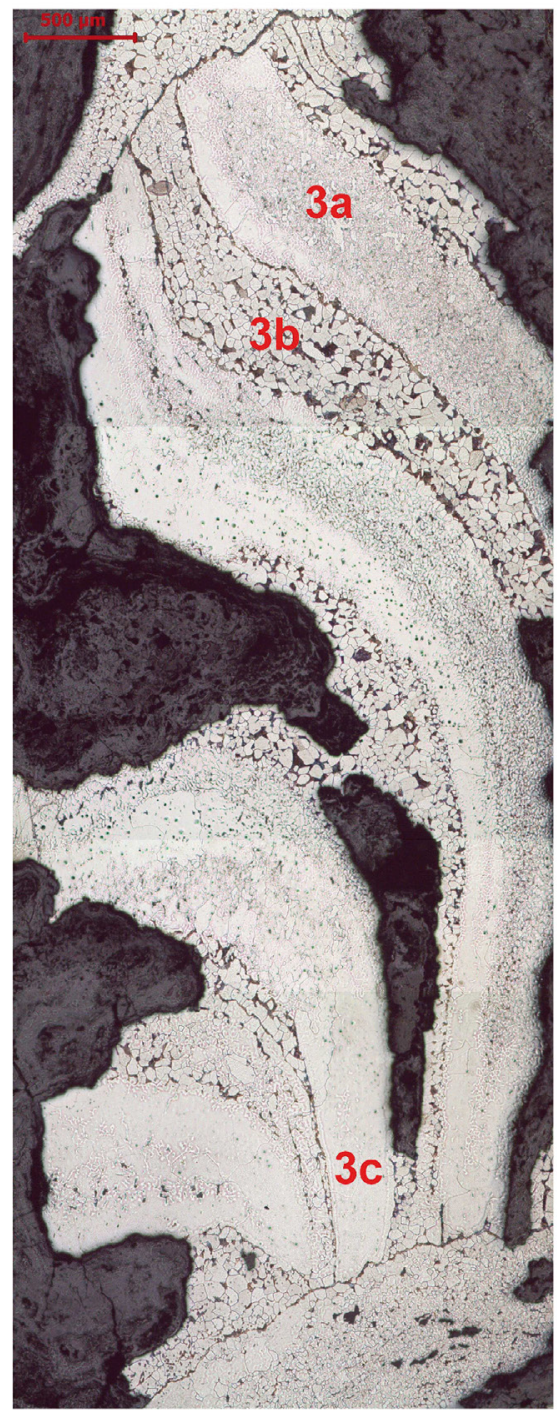

a
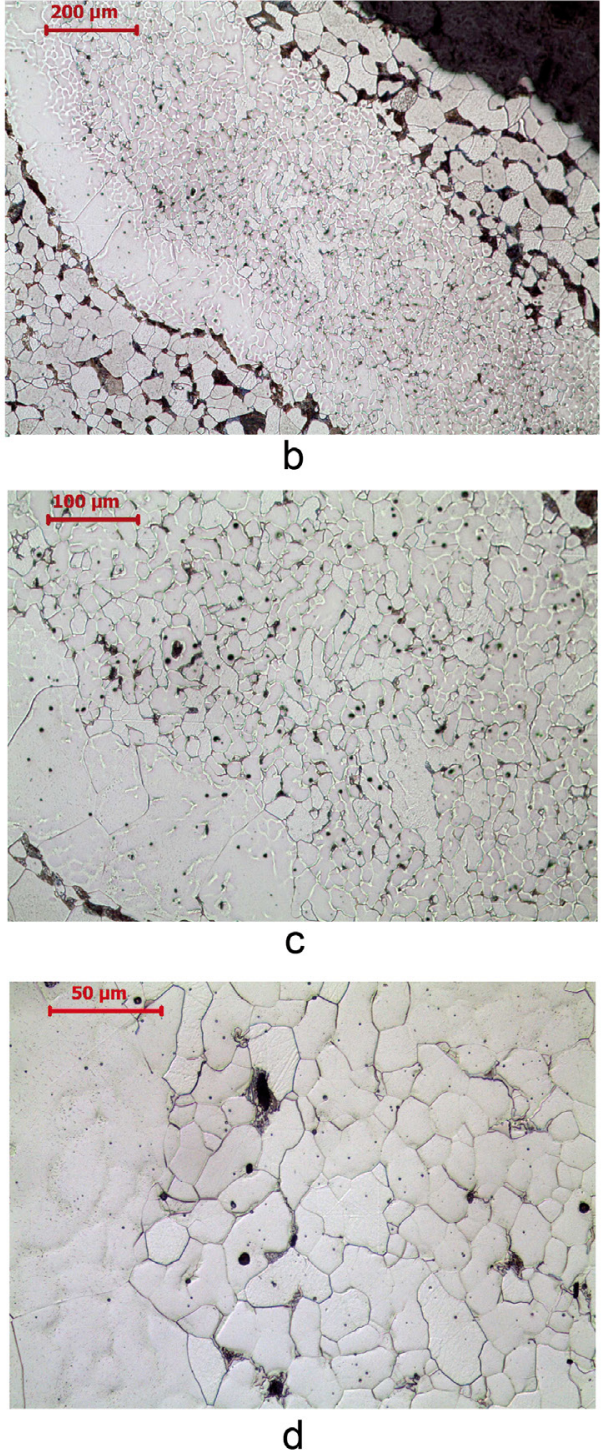

Fig. 6. Spatha CZ-P55, Czaszkowo, Mrągowo District, Prussia, microstructure of the pattern-welded Piece B: a - iron (ferritic) and steel (ferritic-pearlitic) layers in the pattern-welded Piece B in Spot 3; b - iron layer, Zone 3a in Spot 3; c, d-microstructure of the iron layer: ferrite, slag inclusions and ghost structure, Zone 3a in Spot 3. Photo J. Stępiński.

pieces of metal obtained in bloomery process in which ores with and without phosphorus were used. The edges of the sword were in all probability made from soft steel which was perhaps evenly carburised up to $0.2-0.3 \% \mathrm{C}$. However, it should be remembered that the sword blade went through the funeral pyre which may have caused partial decarburisation of the metal. Furthermore, the examined edge is strongly damaged by corrosion and it survived in a vestigial state only. Three pattern-welded rods were used for the manufacture of the blade's core. Each of these was composed of nine alternate layers of phosphorus-rich iron and layers of soft steel. The central piece was additionally twisted, which resulted in a different pattern (not going from flat to flat) in the cross-section of the blade. The presence of material with different contents of carbon and phosphorus in the pattern-welded pieces produced a well-visible pattern in the cross-section of the blade. A considerable hardness of the iron layers in pattern-welded pieces of the metal is related to the presence of phosphorus, which is also implied by the results of slag inclusion analyses. Phosphorus chiefly dissolves in ferrite and hardens it considerably.

In the previous papers discussing this blade, the manufacturing technology was classified as Group B.II.2.1 and perhaps Type B.II.2.1.2, that is, blades with the pattern going through their entire cross-section, composed of twisted and hammer-welded rods. These rods contain layers of metal of different properties. ${ }^{5}$ However, it seems that in the light of the new analysis this classification should be modified and the discussed

${ }^{5}$ Żabiński 2016a, 117-118; Żabiński 2016b, 124-126. 

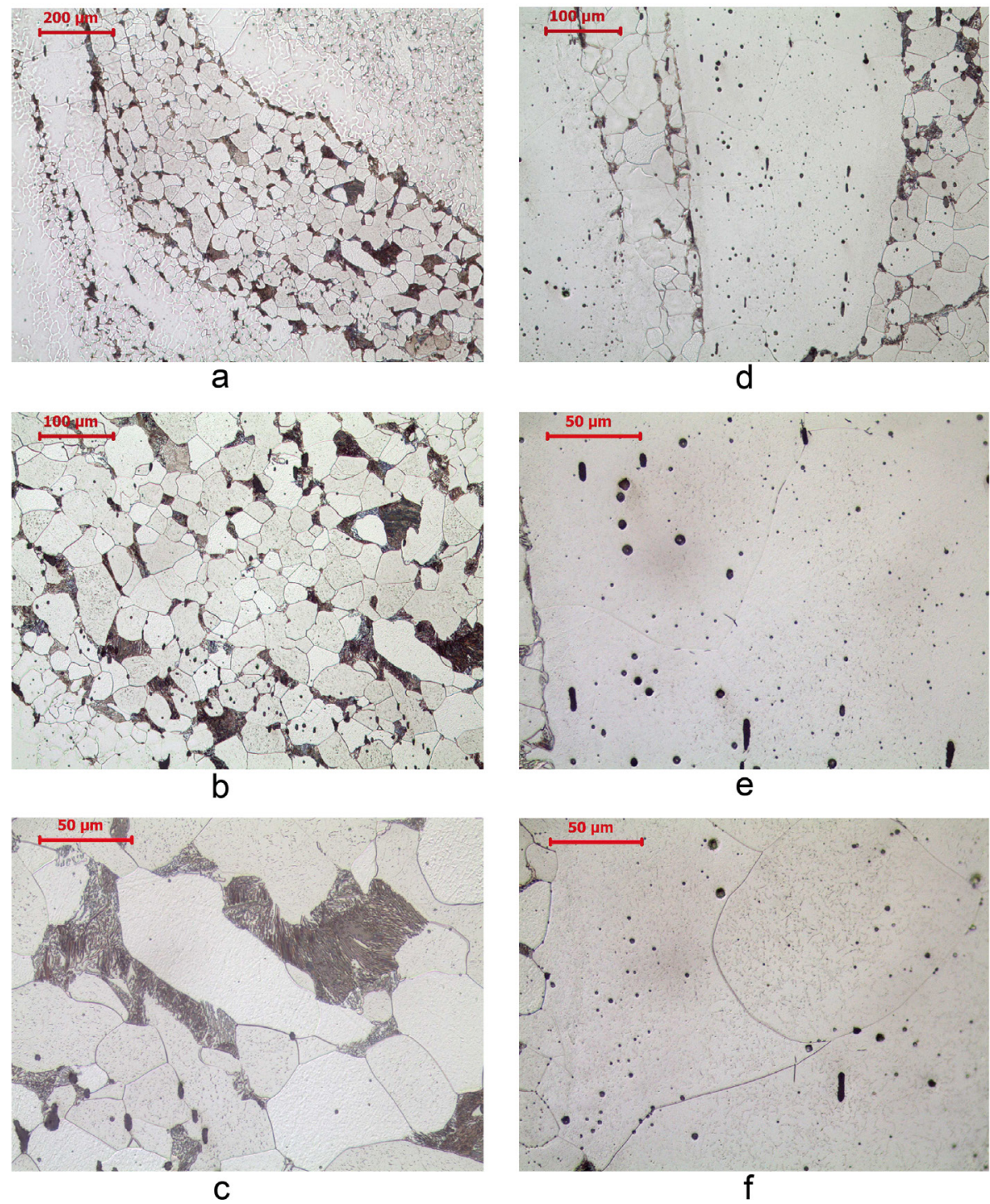

Fig. 7. Spatha CZ-P55, Czaszkowo, Mrągowo District, Prussia, microstructure of the pattern-welded Piece B: a - steel layer, Zone 3b in Spot 3; b, c - ferritic-pearlitic microstructure and slag inclusions in the steel layer, Zone 3b in Spot 3; d - iron layer, Zone 3c in Spot 3; e, $\mathrm{f}$ - coarse-grained ferrite and numerous tiny slag inclusions in the iron layer, Zone $3 \mathrm{c}$ in Spot 3. Photo J. Stępiński.

blade can be classified as Type B.II.2.1.3. The difference between Types B.II.2.1.2 and B.II.2.1.3 consist in the fact that in the latter case some rods are composed of twisted layers while in other rods layers were welded together in a straight manner. ${ }^{6}$

However, this modification of the manufacturing technology's classification hardly changes anything with regard to the chronology of the find. As stated in the previous paper, pattern-welded blades of various individual constructions become more widespread in the period since the late $2^{\text {nd }}$ century $\mathrm{AD}^{7}$ They were quite popular in the Migration Period and the initial stage of the Early

${ }^{6}$ Żabiński et al. 2014, 139-140, Fig. 49.

7 Żabiński 2016b, 125; see also, e.g. Biborski, Ilkjær 2006, 282292; Lang 2009, 234-235; Miks 2007, 54-55; Żabiński et al. 2014 141-142; on the origin of this technology see also Pleiner 1993.
Middle Ages, and then they went out of use at the turn of the $10^{\text {th }}$ and $11^{\text {th }}$ century. The problem of disappearance of pattern-welding in the manufacture of sword blades was thoroughly discussed by P. Kucypera. ${ }^{8}$

Furthermore, it has been proposed that the fact that the blade was pattern-welded may indicate its Roman provenance, with a reservation that this trait may be less indicative in the case of later stages of the Roman Period, with special reference to Phase C2 and later. ${ }^{9}$ For obvious reasons it is impossible to determine

${ }^{8}$ Kucypera 2009; Kucypera 2019; see also, e.g. Lang and Ager 1989, 89, 91, Tab. 7.2, 107, Tab. 7.3, 113-115; Bergman and Arrhenius 2005, 30-33; Miks 2007, 55; Williams 2012, 72-74; Lehmann 2013, 38-42; Żabiński et al. 2014, 142-143.

9 Żabiński 2016b, 125; see also, e.g. Biborski 1978, 56, 112, 114, 145; Biborski et al. 1982; Biborski et al. 1986; Biborski et al. 


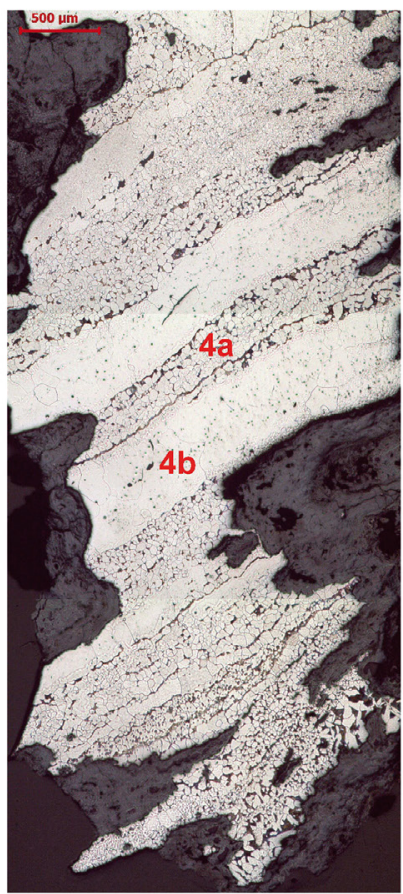

a

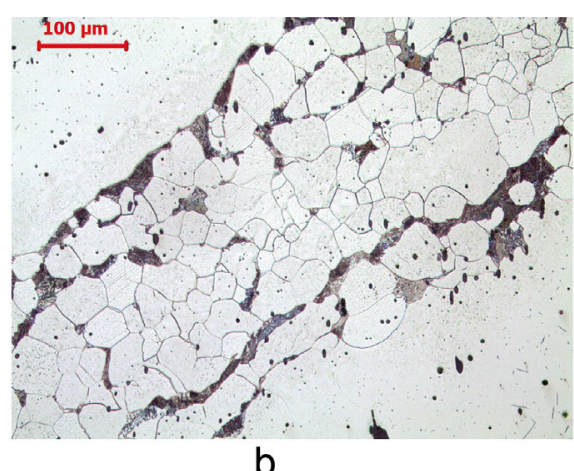

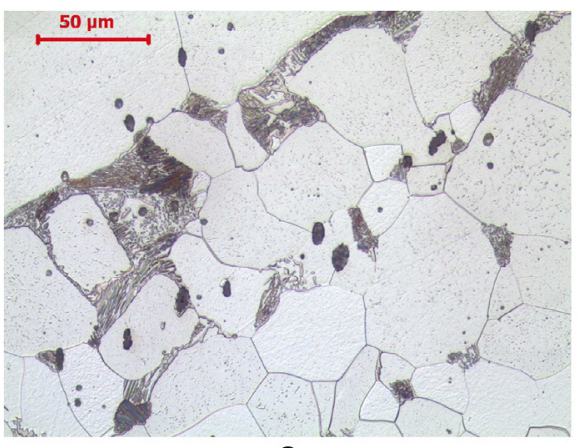

C

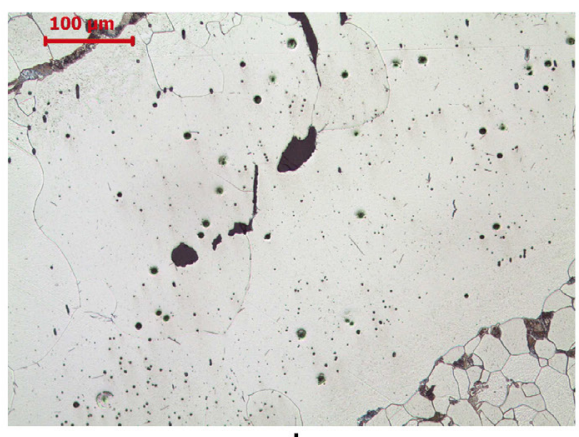

d

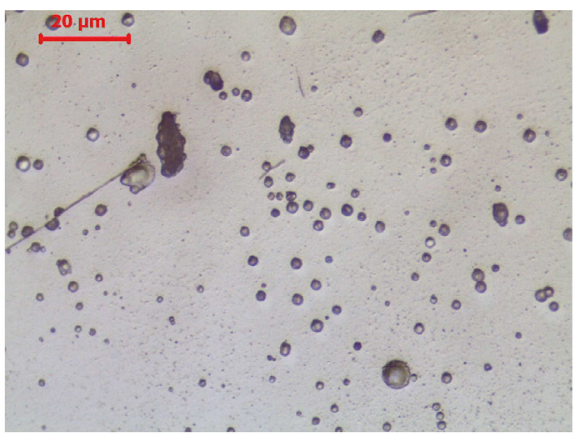

e

Fig. 8. Spatha CZ-P55, Czaszkowo, Mrągowo District, Prussia, microstructure of the pattern-welded Piece C: a - iron (ferritic) and steel (ferritic-pearlitic) layers in the pattern-welded Piece C in Spot 4; b - steel layer, Zone 4a in Spot 4; c - ferritic-pearlitic microstructure and slag inclusions in the steel layer, Zone 4a in Spot 4; $d$ - iron layer, Zone $4 \mathrm{~b}$ in Spot 4; e - coarse-grained ferrite, etching pits and slag inclusions in the iron layer, Zone $4 \mathrm{~b}$ in Spot 4. Photo J. Stępiński.

whether this sword was used in the Germanic or the Balt milieu. Although swords were believed to be rather uncommon among the Balts, ${ }^{10}$ a recent study by B. Kontny points to a considerable number of finds of such weapons and related artefacts, such as scabbard and balteus parts from the Roman Period and the Migration Period in Prussia. ${ }^{11}$

A number of Roman Period and Migration Period swords were pointed out, where similar technologies of

1987; Kaczanowski 1992, 13-22; Biborski et al. 2002; Biborski and Kaczanowski 2003, 113-115; Biborski et al. 2003; Biborski and Ilkjær 2006, 186, 219-220, 282-295; Miks 2007, 54-55; Williams 2012, 51-59; Żabiński et al. 2014, 297.

${ }^{10}$ Kontny 2007, 74-75; Nowakowski 2007, 85-92.

${ }^{11}$ Kontny 2017, 85-107; see also Kontny 2015, 307-318, 315; Kontny 2016, 255-260. manufacture were applied. It is also of interest that many of these blades are known from bog offering deposits and it some cases a Roman provenance can be taken for granted. The following swords can be mentioned here:

- Kvakovce, Slovakia, Type Canterbury-Kopki, Phase B2-C1a; ${ }^{12}$

- Hromovka, Ukraine, Type Lauriacum-Hromovka, Subtype 2, Phase C1b. This sword is undoubtedly of Roman provenance, as its blade is decorated with a Roman-style inlay; ${ }^{13}$

${ }_{12}$ Biborski and Ilkjær 2006, 169.

13 Biborski and Ilkjær 2006, 200, 203, Tab. 19 no. 3, 205, Fig. 136.1; Żabiński et al. 2014, 322, cat. no. 59; see also Piaskowski 1967, 197-199, Fig. 1.19, 200, Fig. 2.19, 207, Figs. 34-37, 208, Fig. 38, 210, 211, Tab. 1, no. 19, 211, 213, Tab. 2, no. 19; Biborski 1978, 82, 84-85, Fig. 40b, 86, 106, Fig. 57d, 111, Tab. 2, 112, 150, cat. no. 46. 


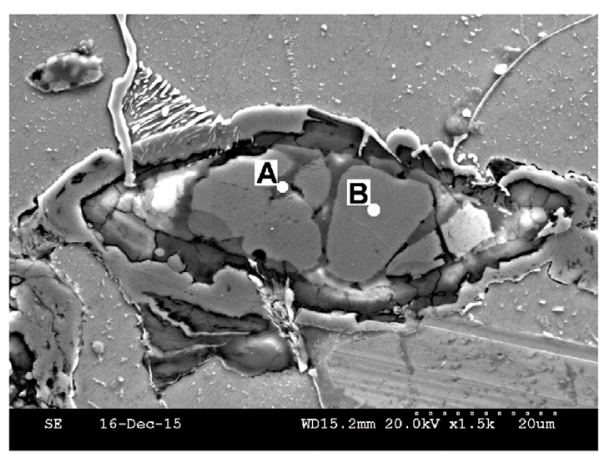

a
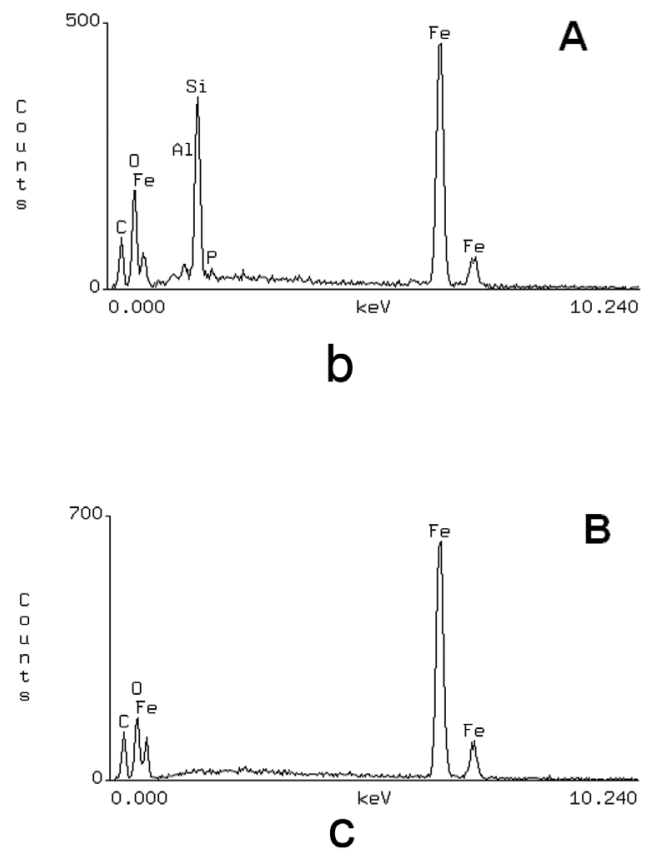
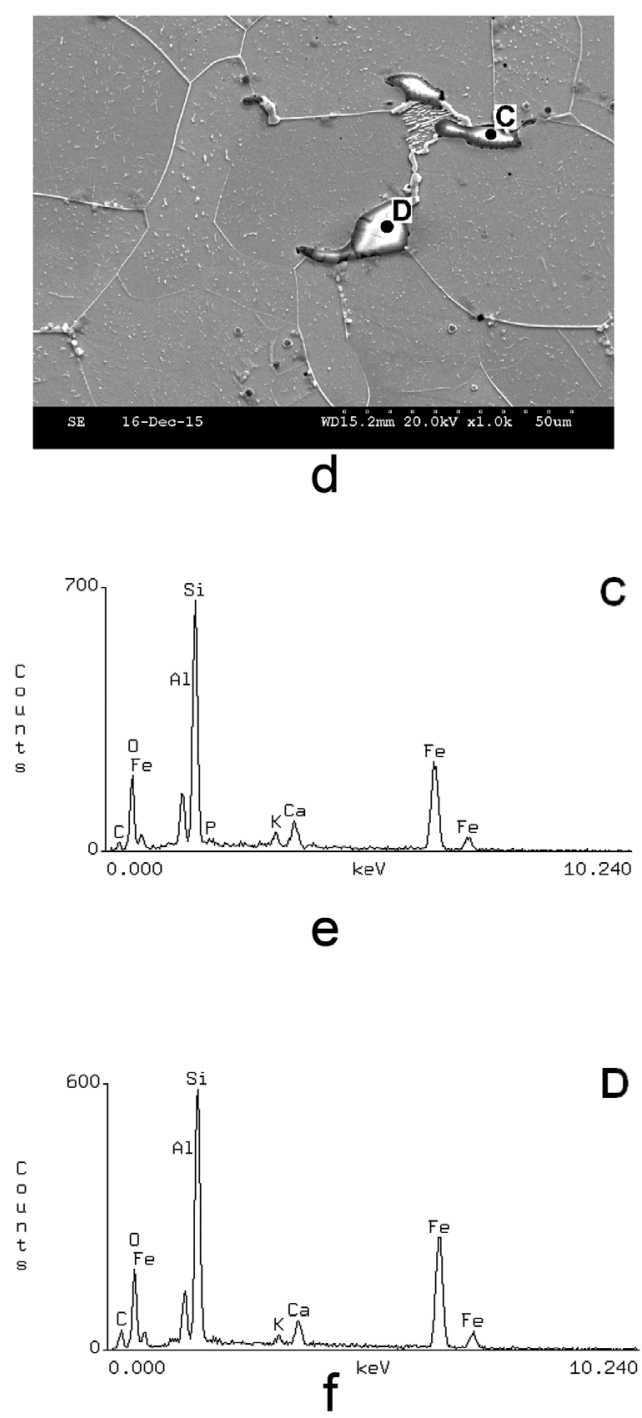

Fig. 9. Spatha CZ-P55, Czaszkowo, Mrągowo District, Prussia, slag inclusions in the edge of the sword with results of the EDS point analysis in spots shown in SEM microphotos: a - multiphase slag inclusion analysed in Points A and B; b - EDS spectrum from Point A, peaks from Fe, Si, O, Al and P can be seen; c-EDS spectrum from Point B, peaks from Fe and $\mathrm{O}$ can be seen; $\mathrm{d}$ - monophase slag inclusions analysed in Points $\mathrm{C}$ and $\mathrm{D}$; e - EDS spectrum from Point $\mathrm{C}$, peaks from $\mathrm{Si}, \mathrm{Fe}, \mathrm{O}, \mathrm{Al}, \mathrm{Ca}$, and $\mathrm{K}$ can be seen;

f - EDS spectrum from Point D, peaks from Si, Fe, O, Al, Ca, and K can be seen. Photo J. Stępiński.

- Jevnaker, Norway, Type Lauriacum-Hromovka; ${ }^{14}$

- Illerup-Ådal, Denmark, inv. no. KABY, Type Vimose-Illerup, Subtype 2, Phase C1b; ${ }^{15}$

- Illerup-Ådal, Denmark, inv. no. KACW, Type Ejsbøl-Sarry, Subtype 1, Phase D; ${ }^{16}$

- Vimose, Denmark, inv. no. 22920, Type NydamKragehul, Subtype 1, Phase C1b-C2. In this case the Roman origin of this blade is testified to by a stamp which can be seen on the tang: ${ }^{17}$

14 Biborski and Ilkjær 2006, 200.

15 Biborski and Ilkjær 2006, 219, 223, Tab. 25 no. 9, 224, Fig. 142.1, 282, 284, Tab. 53 no. 9.

${ }^{16}$ Biborski and Ilkjær 2006, 286, Tab. 56 no. 37.

${ }_{17}$ Biborski and Ilkjær 2006, 238, 239, Tab. 31 no. 18; on Vimose double-edged swords in general see also Pauli Jensen 2008, 118-127.
- Ejsbøl, Denmark, inv. nos. 4461 and 9289, Type Vøien-Hedelisker, Subtype 1 from Phase C2 and Subtype 1 from Phase C2-D; ${ }^{18}$

- Nydam, Denmark, inv. no. FS4329, Type VøienHedelisker, Subtype 1 from Phase C2- ${ }^{19}$. It must also be said that eight swords from Nydam were technologically examined by V. F. Buchwald and various types of pattern-welding were identified in their blades. None of these is an exact analogy to the technology in the discussed sword from

${ }_{18}$ Biborski and Ilkjær 2006, 254-255, Tab. 37 nos. 2, 3, Fig. 154.2.

${ }_{19}$ Bemmann and Bemmann 1998b, 52, cat. no. 411, Pl. 38; Biborski and Ilkjær 2006, 254, Tab. 37 no. 6; on Nydam swords in general see also Bemmann and Bemmann 1998a, 158-161, 249-250, 259260, 312-313; Bemmann and Bemmann 1998b, 48-67, P1. 32-53. 


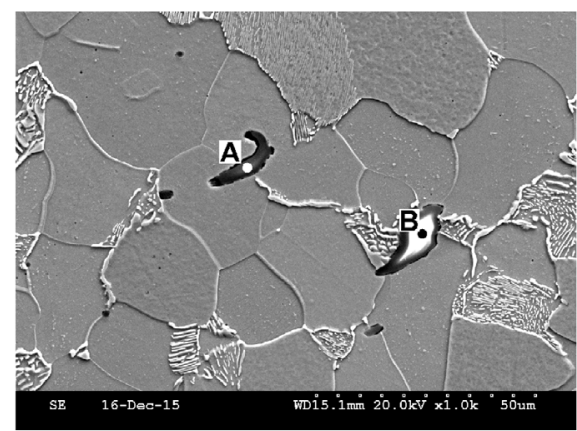

a

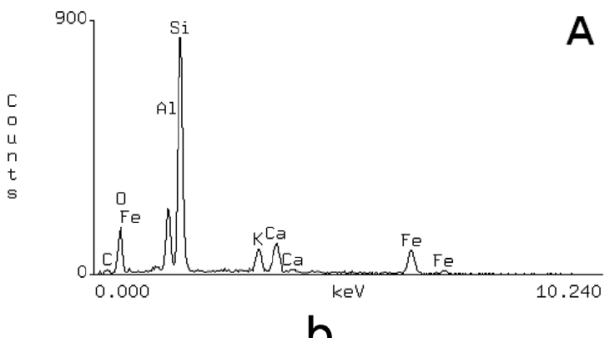

b

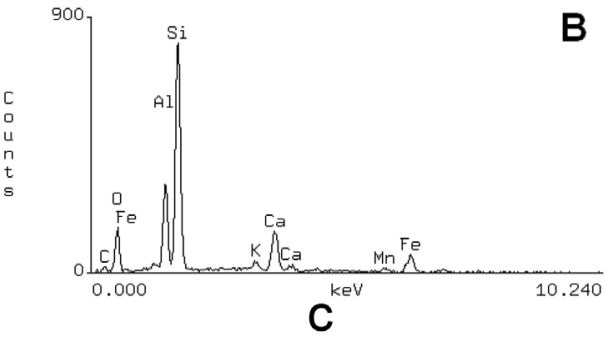

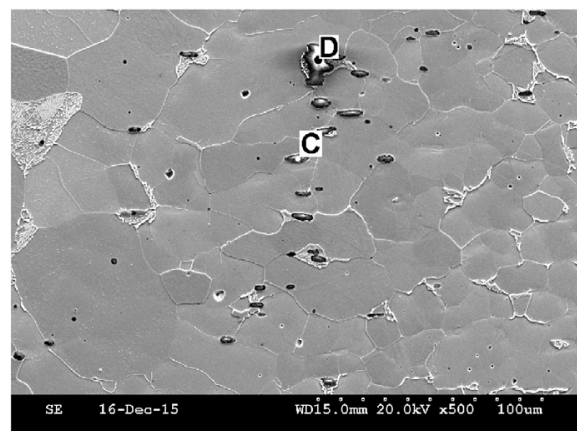

d

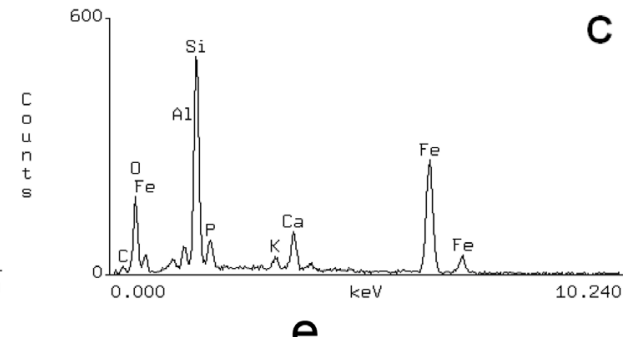

e

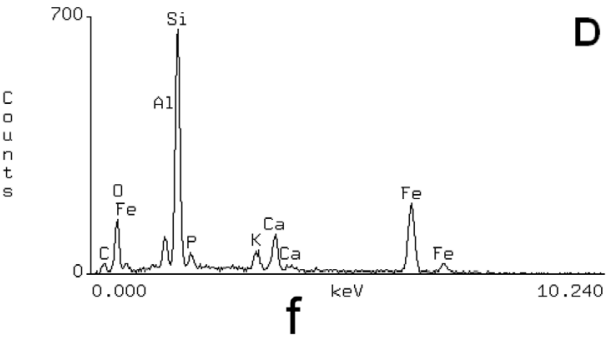

Fig. 10. Spatha CZ-P55, Czaszkowo, Mragowo District, Prussia, slag inclusions in the pattern-welded Piece A with results of the EDS point analysis in spots shown in SEM microphotos: $a$ - slag inclusions in the steel layer analysed in Points A and B; b - EDS spectrum from Point A, peaks from Si, Al, O, Fe, Ca, and $\mathrm{K}$ can be seen; c- EDS spectrum from Point B, peaks from Si, Al, O, Ca, Fe, and K can be seen; $\mathrm{d}$ - slag inclusions in the iron layer analysed in Points $\mathrm{C}$ and $\mathrm{D}$; e-EDS spectrum from Point $\mathrm{C}$, peaks from $\mathrm{Si}, \mathrm{Fe}, \mathrm{O}, \mathrm{Ca}, \mathrm{P}, \mathrm{Al}$, and $\mathrm{K}$ can be seen; f - EDS spectrum from Point D, peaks from Si, Fe, O, Ca, Al, K, and P can be seen. Photo J. Stępiński.

Lake Nidajno, albeit no. 5409 seems to be the closest; ${ }^{20}$

- Dąbrówka, Poland, Type Ejsbøl-Sarry, Subtype 1.2, Phase C2-D; ${ }^{21}$

- Korzeń, Poland, Grave 41b, Type Ejsbøl-Sarry, Phase $\mathrm{D} ;{ }^{22}$

- Oblin, Poland, Grave 45b, Type LachmirowiceApa, Subtype 1, Variant 1, Phase B2. Also in this case the Roman provenance of this blade is demonstated by the presence of a copper inlay of Mars; ${ }^{23}$

${ }^{20}$ Buchwald 2005, 287-299, Figs. 309-309; see also Williams 2012, 70-71, Fig. 3.

${ }^{21}$ Biborski and Ilkjær 2006, 260, 262, Tab. 40 no. 2.

${ }^{22}$ Biborski and Ilkjær 2006, 260, 262, Tab. 40 no. 31.

${ }^{23}$ Biborski et al. 2003, 98, Fig. 1e, 5, 100, 105, Fig. 3; Biborski and Ilkjær 2006, 187, Tab. 11, no. 14, 188, Fig. 182. 4; Biborski et al. 2007, 131, Fig. 1e, 137, 139, Fig. 6; Żabiński et al. 2014, Appendix, 309, no. 28.
- Oblin, Poland, Grave 62, Type Canterbury-Kopki, Subtype 2, Phase B2; ${ }^{24}$

- Hegykö, Hungary, the $6^{\text {th }}$ century; ${ }^{25}$

- Wickhambreaux, England, the $6^{\text {th }}-7^{\text {th }}$ century; ${ }^{26}$

- Bifrons, England, the $6^{\text {th }}-7^{\text {th }}$ century ${ }^{27}$

- Aylesford, England, the $6^{\text {th }}-7^{\text {th }}$ century. ${ }^{28}$

${ }^{24}$ Biborski et al. 2003, 98, Fig. 1g, 7, 101, 105, Fig. 4; Biborski and Ilkjær 2006, 172, Tab. 5, 8; Biborski et al. 2007, 131, Fig. 1g, 141-143, Fig. 8; Żabiński et al. 2014, Appendix, 310, 30.

${ }^{25}$ La Salvia 1998, 44-52, Fig. 3, 4, 5.1, 6, 7, 63; La Salvia 2007, 36-38, 114, Fig. 11a; see also Williams 2012, 73.

${ }_{26}$ Tylecote and Gilmour 1986, 151, Fig. 63-S12, 156, Tab. N-S12, 182-185, Fig. 77.

${ }^{27}$ Tylecote and Gilmour 1986, 155, Fig. 63-S49, 156, Tab. N-S49, 185-186, Fig. 78.

28 Tylecote and Gilmour 1986, 152, Fig. 63-S18, 157, Tab. N-S18, 193, Fig. 82, 195-197. 


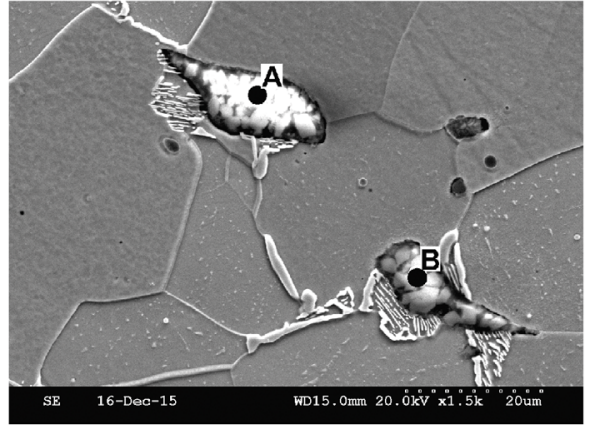

a

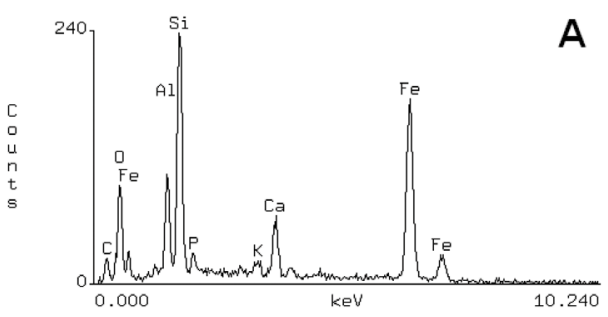

b

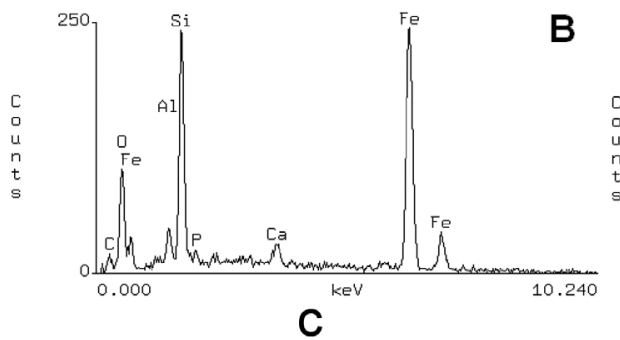

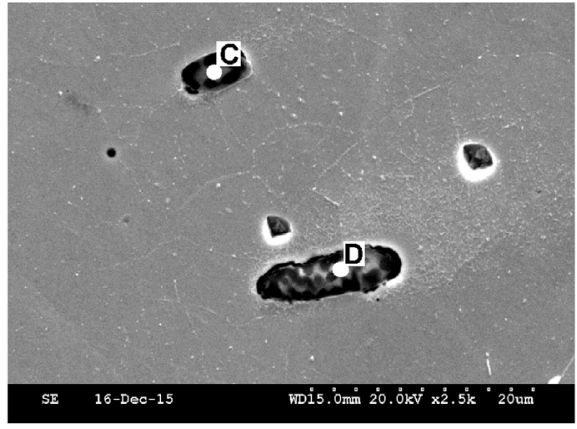

d

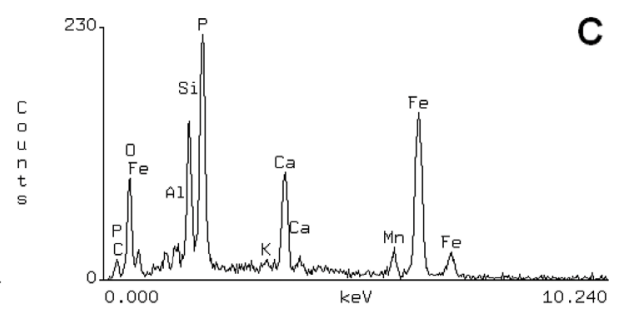

e

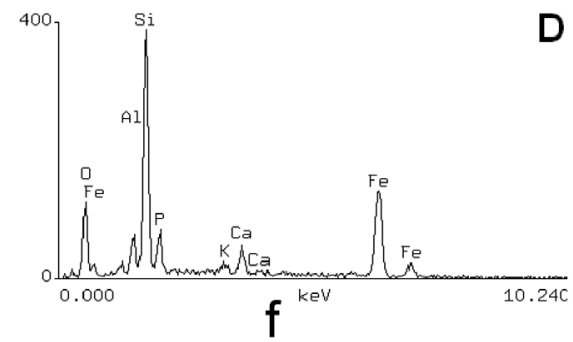

Fig. 11. Spatha CZ-P55, Czaszkowo, Mrągowo District, Prussia, slag inclusions in the pattern-welded Piece B with results of the EDS point analysis in spots shown in SEM microphotos: $a$ - slag inclusions in the steel layer analysed in Points A and B; b - EDS spectrum from Point A, peaks from Si, Fe, O, Ca, P, Al, and $\mathrm{K}$ can be seen; c-EDS spectrum from Point B, peaks from $\mathrm{Si}, \mathrm{Fe}, \mathrm{O}, \mathrm{Al}, \mathrm{Ca}$, and $\mathrm{P}$ can be seen; $\mathrm{d}$ - slag inclusions in the iron layer analysed in Points $\mathrm{C}$ and $\mathrm{D} ; \mathrm{e}-\mathrm{EDS}$ spectrum from Point $\mathrm{C}$, peaks from $\mathrm{P}, \mathrm{Fe}, \mathrm{Si}, \mathrm{Ca}, \mathrm{O}, \mathrm{Mn}$,

$\mathrm{Al}$, and $\mathrm{K}$ can be seen; f - EDS spectrum from Point D, peaks from Si, Fe, O, P, Ca, Al, and K can be seen. Photo J. Stępiński.

\section{Conclusions}

The sword blade from Czaszkowo we have discussed deserves interest in every respect. Its sophisticated manufacturing technology, that is, pattern-welding, demonstrates that the blade was made by a highly competent specialist and was of extraordinary utilitarian and aesthetic quality. Due to the state of preservation of the artefact (prolonged heating in the funeral pyre and very advanced corrosion of the edge parts), it is not possible any more to state whether the blade underwent any other procedures, such as thermal treatment (e.g. quenching). It cannot be excluded that it was manufactured in the territory of the Roman Empire; regrettably, this cannot be proved unequivocally. Although several blades which were made in a similar manner can be pointed out, no exact technological counterpart is known to the author. Due to the state of preservation of the artefact, no typological classification is possible and its proposed chronology must remain within a general framework of the Late Roman and the Migration Period.

As stated above, it cannot be clearly determined whether the discussed sword was in use in the Balt, the Germanic or other cultural milieu. It seems, however, that the very fact of the discovery of this blade and other swords in Lake Nidajno suggests that swords were not as rare in the Balt zone during the Roman Period as it has been previously assumed. 


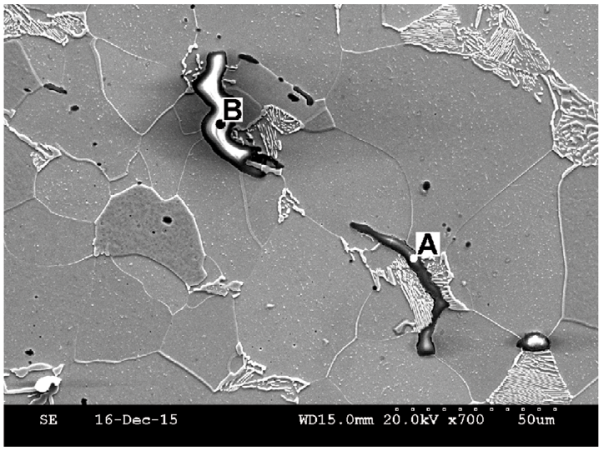

a

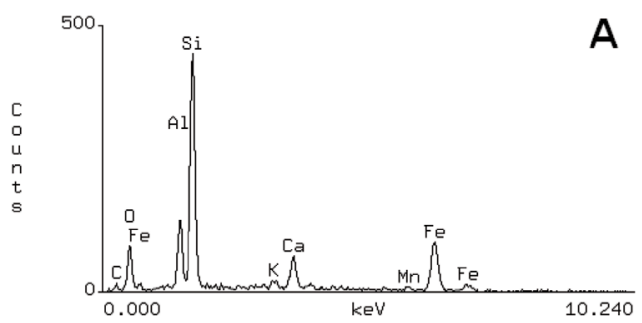

b

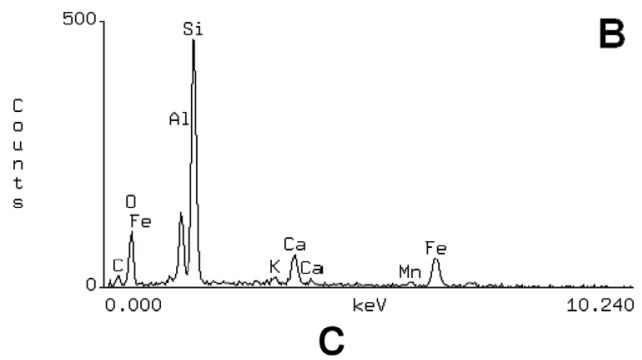

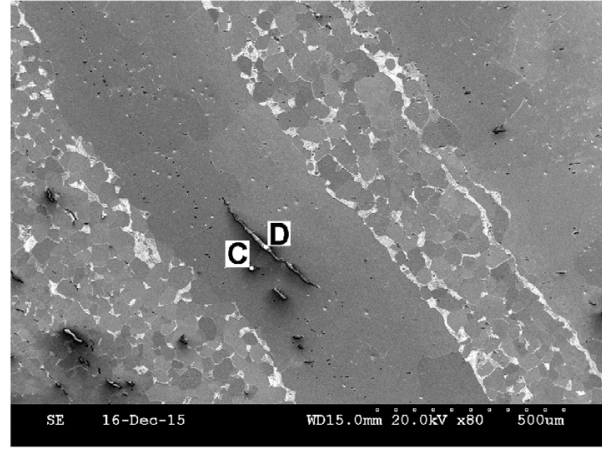

d
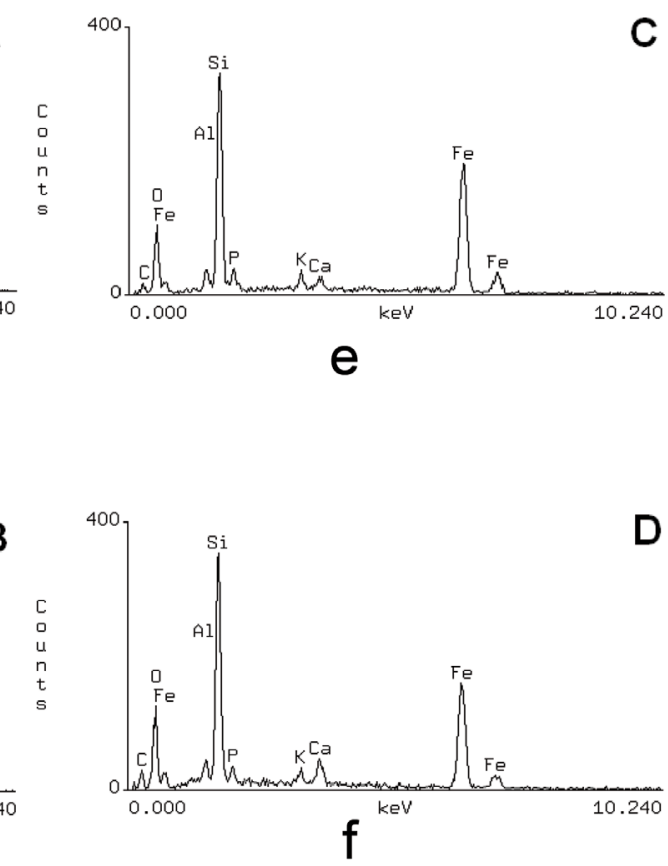

Fig. 12. Spatha CZ-P55, Czaszkowo, Mrągowo District, Prussia, slag inclusions in the pattern-welded Piece C with results of the EDS point analysis in spots shown in SEM microphotos: $a$ - slag inclusions in the steel layer analysed in Points A and B; b - EDS spectrum from Point A, peaks from Si, Fe, Al, O, Ca, K, and Mn can be seen; c-EDS spectrum from Point B, peaks from Si, Al, O, Fe, Ca, K, and $\mathrm{Mn}$ can be seen; $\mathrm{d}$ - slag inclusions in the iron layer analysed in Points $\mathrm{C}$ and D; e-EDS spectrum from Point C, peaks from Si, Fe, O, P,

K, Al, and Ca can be seen; f - EDS spectrum from Point D, peaks from Si, Fe, O, Ca, Al, P, and K can be seen. Photo J. Stępiński.

\section{Bibliography}

Bemmann G., Bemmann J. 1998a. Der Opferplatz von Nydam. Die Funde aus den älteren Grabungen: Nydam-I und Nydam-II. Vol. 1: Text. Neumünster.

Bemmann G., Bemmann J. 1998b. Der Opferplatz von Nydam. Die Funde aus den älteren Grabungen: Nydam-I und Nydam-II. Vol. 1: Katalog und Tafeln. Neumünster.

Bergman L. T., Arrhenius B. 2005. Excavations at Helgö XV. Weapon Investigations. Helgö and the Swedish Hinterland. Stockholm.

Biborski M. 1978. Miecze z okresu wplywów rzymskich na terenie kultury przeworskiej. "Materiały Archeologiczne" $18,53-163$.

Biborski M., Ilkjær J. 2006. Illerup Ådal 11: Die Schwerter. Textband. Jutland Archaeological Society Publications 25: 11. Aarhus.

Biborski M., Kaczanowski P. 2003. Uwagi o technologii mieczy jako kryterium identyfikacji importów broni rzymskiej. In: A. Bursche, R. Ciołek (eds.), Antyk i barbarzyńcy. Księga dedykowana profesorowi Jerzemu Kolendo $w$ siedemdziesiata rocznice urodzin. Warszawa, 109-120. 
Biborski M., Kaczanowski P., Kędzierski Z., Stępiński J. 1982. Metallographische Untersuchungen als Kriterium einer Identifikation römischer Schwerter. In: J. Piaskowski, M. Biborski (eds.), Ancient Iron Manufacture Centres in Northern Central Europe. Archaeologia Interregionalis 3. Warszawa, Kraków, 65-98.

Biborski M., Kaczanowski P., Kędzierski Z., Stępiński J. 1986. Ergebnisse der metallographischen Untersuchungen von römischen Schwertern aus dem Vindonissa-Museum Brugg und dem Römermuseum Augst. "Gesellschaft pro Vindonissa. Jahresbericht" 1985, 45-80.

Biborski M., Kaczanowski P., Kędzierski Z., Stępiński J. 2002. Badania nad technologia mieczy z młodszego okresu przedrzymskiego z obszaru kultury przeworskiej. In: J. Andrzejowski, R. Prochowicz, A. Żórawska (eds.), Varia Barbarica. Zenoni Woźniak ab amicis dedicata. Monumenta Archaeologica Barbarica. Series Gemina 1. Warszawa, Lublin, 81-104.

Biborski M., Kaczanowski P., Kędzierski Z., Stępiński J. 2003. Manufacturing Technology of Double- and SingleEdged Swords from the $1^{\text {st }} B C$ and $2^{\text {nd }}$ century $A D$. In: Archaeometallurgy in Europe. International Conference 24-25-26 September 2003. vol. 1. Milano, 97-108.

Biborski M., Kaczanowski P., Kędzierski Z., Stępiński J. 2007. Metallographische Untersuchungen der zwei-und einschnedigen Schwerter vom Gräberfeld der Przeworsk-Kultur in Oblin. In: K. Czarnecka, Oblin. Ein Gräberfeld der Przeworsk-Kultur in Südmasowien. Monumenta Archaeologica Barbarica 13. Warszawa, 131-146.

Buchwald V. F. 2005. Iron and Steel in Ancient Times. Historisk-filosofiske Skrifter 29. Copenhagen.

Kaczanowski P. 1992. Importy broni rzymskiej na obszarze europejskiego Barbaricum. Uniwersytet Jagielloński. Rozprawy Habilitacyjne 244. Kraków.

Kontny B. 2007. Najwcześniejsze elementy uzbrojenia w kulturze bogaczewskiej w świetle zewnętrznych wpływów kulturowych. In: A. Bitner-Wróblewska (ed.), Kultura bogaczewska w 20 lat później. Warszawa, 73-111.

Kontny B. 2015. This Came Out of the Swamp. Wolka See Revisited. In: B. Kontny (ed.), Ubi tribus faucibus fluenta Vistulae fluminis ebibuntur. Jerzy Okulicz-Kozaryn in memoriam. Światowit Supplement Series B: Barbaricum 11. Warszawa, 307-331.

Kontny B. 2016. Imitation and Inspiration in the Field of Militaria at Szwajcaria Cemetery (the Sudovian Culture). The Case of a 'Princely Grave' from Barrow 2. "Journal of Roman Military Equipment Studies" 17, 255-268.

Kontny B. 2017. Really Unique? On the Swords in the West Balt Circle. "Študijné Zvesti Archeologického Ústavu SAV" 61, 85-116.

Kucypera P. 2009. Problem zaniku stosowania technologii dziwerowania w produkcji średniowiecznych głowni mieczowych. In: M. Bogacki, M. Franz, Z. Pilarczyk (eds.), Gospodarka ludów Morza Bałtyckiego 1: Starożytność i średniowiecze. Mare Integrans. Studia nad dziejami wybrzeży Morza Battyckiego. Materiały z IV Międzynarodowej Sesji Naukowej Dziejów Ludów Morza Bałtyckiego, Wolin 1-3 sierpnia 2008. Toruń, 245-256.

Kucypera P. 2019. Pattern-Welding Technique in Early Medieval Sword-Making. In: L. Poláček, P. Koư̌il (eds.), Bewaffnung und Reiterausrüstung des 8 bis 10 Jahrhunderts in Mitteleuropa. Waffenform und Waffenbeigaben bei den mährischen Slawen und in den Nachbarländern. Internationale Tagungen in Mikulčice 9. Brno, 421-430.

La Salvia V. 1998. Archaeometallurgy of Lombard Swords. From Artifacts to a History of Craftsmanship. Firenze.

La Salvia V. 2007. Iron Making During the Migration Period: the Case of the Lombards. British Archaeological Report International Series 1715. Oxford.

Lang J. 2009. A Consideration of the Methods of Constructing Iron Sword Blades in the Pre-medieval Period. In: $2^{\text {nd }}$ International Conference Archaeometallurgy in Europe 2007, Aquileia, Italy, 17-21 June 2007. Milano, 232-240.

Lang J. S. R., Ager B. M. 1989. Swords of the Anglo-Saxon and Viking Periods in the British Museum: a Radiographic Study. In: S. Hawkes Chadwick (ed.), Weapons and Warfare in Anglo-Saxon England. Oxford University Committee for Archaeology Monograph 21. Oxford, 85-122.

Lehmann U. 2013. Studien zu frühmittelalterlichen Schwertschmiedetechniken mittels 3-D-RöntgenComputertomografie. "Archäometrie und Denkmalpflege", 38-43.

Miks Chr. 2007. Studien zur römischen Schwertbewaffnung in der Kaiserzeit. Kölner Studien zur Archäologie der römischen Provinzen 8. Rahden.

Nowakiewicz T. 2015. Bagienne stanowisko ofiarne w dawnym jeziorze Nidajno (Czaszkowo, Mazury): zarys problematyki badawczej, uwarunkowania terenowe i zagadnienia metodyczne. In: S. Wadyl, M. Karczewski, M. Hoffmann (eds.), Materiały do archeologii Warmii i Mazur 1. Warszawa, Białystok, 133-147.

Nowakiewicz T. (ed.) 2016. Starożytne miejsce ofiarne w dawnym jeziorze Nidajno na Mazurach. Wyniki badań laboratoryjnych wybranych zabytków / Ancient Sacrificial Place in Former Lake Nidajno in Masuria. Results of Laboratory Analyses of Selected Finds. Depozyty ofiarne z polskich bagien i jezior 2 / The Offerings Once Made in Poland's Bogs and Lakes 2. Warszawa. 
Nowakiewicz T., Rzeszotarska-Nowakiewicz A. 2011. Czaszkowo, woj. warmińsko-mazurskie. Badania w roku 2010. Depozyt jeziorny czy miejsce kultu?. "Światowit” 8(49). Fasc. B, 179-182.

Nowakiewicz T., Rzeszotarska-Nowakiewicz A. 2012. Jezioro Nidajno koło Czaszkowa na Mazurach: niezwykte miejsce kultu z okresu późnej starożytności / Lake Nidajno near Czaszkowo in Masuria: a unique sacrificial site from Late Antiquity. Warszawa

Nowakowski W. 2007. Aestorum gladii. Swords in the West Balt Circle in the Roman Period. "Archaeologia Baltica" 8, 85-94.

Pauli Jensen X. 2008. Våben fra Vimose: Bearbejdning og tolkning af et gammelkendt fund. PhD diss., University of Copenhagen.

Piaskowski J. 1967. Metaloznawcze badania starożytnych przedmiotów żelaznych z dorzecza Prypeci, Dniestru i Bugu. "Materiały Archeologiczne" 8, 197-214.

Pleiner R. 1993. The Celtic Sword. Oxford.

Tylecote R. F., Gilmour B. J. J. 1986. The Metallography of Early Ferrous Edge Tools and Edged Weapons. British Archaeological Reports. British Series 155. Oxford.

Williams A. R. 2012. The Sword and the Crucible. A History of the Metallurgy of European Swords up to the $16^{\text {th }}$ Century. Leiden, Boston.

Żabiński G. 2016a 2.1. Wyniki analiz żelaznych głowni mieczowych z Nidajna / The Results of Analyses of Sword Blades from Nidajno. In: T. Nowakiewicz (ed.), Starożytne miejsce ofiarne w dawnym jeziorze Nidajno na Mazurach. Wyniki badań laboratoryjnych wybranych zabytków / Ancient Sacrificial Place in Former Lake Nidajno in Masuria. Results of Laboratory Analyses of Selected Finds. Depozyty ofiarne z polskich bagien i jezior 2 / The Offerings Once Made in Poland's Bogs and Lakes 2. Warszawa, 88-122.

Żabiński G. 2016b. 2.2. Omówienie wyników badań technologicznych żelaznych mieczy typu spatha z Nidajna I A Discussion on The Results of Technological Analyses of Iron Swords of Type Spatha from Nidajno. In: T. Nowakiewicz (ed.), Starożytne miejsce ofiarne w dawnym jeziorze Nidajno na Mazurach. Wyniki badań laboratoryjnych wybranych zabytków / Ancient Sacrificial Place in Former Lake Nidajno in Masuria. Results of Laboratory Analyses of Selected Finds. Depozyty ofiarne z polskich bagien i jezior 2 / The Offerings Once Made in Poland's Bogs and Lakes 2. Warszawa, 123-130.

Żabiński G., Stępiński J., Biborski M. 2014. Technology of Sword Blades from the La Tène Period to the Early Modern Age. The Case of What Is Now Poland. Oxford. 